\title{
Tekst dyskursywny czy literacki? Krasińskiego dwie relacje z audiencji u Napoleona III
}

\author{
(opracowanie tekstologiczne Emilia Zaręba)
}

Zygmunt Krasiński po raz pierwszy spotkał się z Napoleonem III 4 kwietnia 1857 roku, data ta widnieje również na początku relacji z wydarzenia pióra poety. Tę samą datę podaje Zbigniew Sudolski ${ }^{1}$; o spotkaniu wspomina też Stanisław Małachowski ${ }^{2}$. Tekst relacji z audiencji u cesarza nie ukazał się drukiem za życia poety. Pierwodruk, który z racji braku rękopisów stał się podstawą tekstową przygotowywanej edycji, ukazał się w roku 1912 w wydaniu jubileuszowym Pism Zygmunta Krasińskiego w tomie Pisma filozoficzne i polityczne. Od tamtej pory wyszedł drukiem jeszcze tylko dwa razy: w jedenastym tomie Dziet pod redakcją Leona Piwińskiego (1931) oraz w Pismach filozoficznych i politycznych opracowanych przez Pawła Hertza (1999). We wszystkich wydaniach występował pod tytułem nadanym mu przez Jana Czubka, czyli Pierwsze postuchanie u Napoleona III. Tekst Drugiego postuchania u Napoleona III ${ }^{\beta}$ przeszedł podobne dzieje, co relacja z pierwszej audiencji. Pierwodruk ukazał się w wydaniu jubileuszowym, następnie w Dzietach pod redakcją Piwińskiego oraz w Pismach filozoficznych i politycznych w opracowaniu Pawła Hertza. Rękopisy obydwu tekstów znajdowały się w Bibliotece Ordynacji Krasińskich i spłonęły w czasie powstania warszawskiego. Podstawę tekstową dla powstającej właśnie edycji stanowi więc pierwodruk.

O pierwszej audiencji Zygmunta u cesarza tak pisał Stanisław Małachowski:

W jesieni roku 1856 otrzymał Krasiński po raz pierwszy pozwolenie udania się do Paryża. Niezwłocznie też opuścił księstwo Badeńskie i pojechał do tej pierwszej europejskiej stolicy [...]. Najważniejszą jednak czynnością Krasińskiego w czasie tego swego pobytu w Paryżu było osobiste tajemne widzenie się z cesarzem Napo-

Z. Sudolski, Krasiński. Opowieść biograficzna, Warszawa 1997, s. 509.

S. Małachowski, Krótki rys życia i pism Zygmunta Krasińskiego, Kraków 1876, s. 65-67.

Tytuł, podobnie jak w przypadku pierwszego tekstu, został nadany przez Jana Czubka. 
leonem w zamku Tuilleryjskim. Właśnie to była chwila kongresu państw Europejskich po ukończonej wojnie wschodniej. Zygmunt, pojmując całą ważność chwili i przedmiotów, jakie traktowane będą na tym kongresie, sądząc, że też i polska kwestia nie powinna być zapomnianą, opuszczoną, ani pominiętą; mając ułatwiony przystęp do Cesarza, czuł się w obowiązku udać się do niego, użyć wszelkich sił i argumentów, aby go nakłonić do wniesienia i popierania tejże na kongresie. Otrzymał posłuchanie, na którem cesarz słuchał go z wielkim zajęciem i zadawał pytania o położeniu Polaków pod rządami: rosyjskim, pruskim i austriackim, które znał bardzo niedokładnie. Najskwapliwiej dopytywał się i żądał objaśnienia o stosunkach wewnętrznych i zewnętrznych, tego ostatniego państwa. Pomiędzy innymi pytaniami wywiadywał się o byt i znaczenie religii grecko-unickiej, o której żadnego nie miał wyobrażenia, w końcu zapewniał o swej życzliwości dla polskiej sprawy4.

Rozmowa podczas audiencji dotyczyła głównie problemów Polski pod zaborami rosyjskim, pruskim i austriackim. Krasiński podkreślał konieczność odzyskania niepodległości przez Polskę - uważał, że takie rozwiązanie byłoby najkorzystniejsze nie tylko dla Francji, lecz i dla całej Europy 5 . Obietnice Napoleona były jednak mgliste ${ }^{6}$, Krasiński zauważył nawet pewną ogólnikowość jego wypowiedzi (cesarz nie obiecał mu niczego konkretnego). Wyraźnie natomiast sprzeciwił się otwartej wojnie z Rosją. Mimo negatywnego wydźwięku rozmowy, u poety obudziły się nadzieje na polepszenie losu narodu polskiego?.

Druga audiencja u cesarza odbyła się 20 lipca 1858 roku w Plombières, gdzie Krasiński przebywał na leczeniu. Bawił tam wówczas również Napoleon III oraz przywódca Włoch, Camillo Cavour. Poeta wspominał o niej w dwóch listach do ojca:

[...] Byłem też zaraz nazajutrz u księżny Hamilton - powiedziała mi, bym poszedł zapisać się do Cesarza, że taki tu zwyczaj, i od niej wychodząc, zapisałem się.8.

[...] Byłem wczoraj u Pana dachówkarnianego - najuprzejmiejszy, najgrzeczniejszy ze znanych mi panów domu jakiego. Dość długom siedział; na ciele dobrze wygląda, ale jakoś żywszym i weselszym, choć bledszym i chudszym był dawniej?.

Wizyta trwała krótko, cesarz był małomówny. Zbigniew Sudolski komentuje drugie spotkanie Napoleona III z Krasińskim w taki oto sposób: „Tak więc wołanie Krasińskiego o wojnę powszechną w imię pokrzywdzonych narodowości i próba pozyskania Francji dla sprawy polskiej skończyły się tym razem zupełnym niepowodzeniem"10. W relacji poety łatwo jest zauważyć nutę zawodu i rozczarowania. Pełen nadziei po poprzedniej audiencji u cesarza, romantyk zostal „sprowadzony na ziemię" - cesarz po prostu nie przywiązywał większej wagi do sprawy polskiej.

Warto zauważyć, że oba teksty nie ukazały się w wydaniu Dziet literackich przygotowanym przez Pawła Hertza (1973). Znamienna jest data publikacji owej edycji - lata

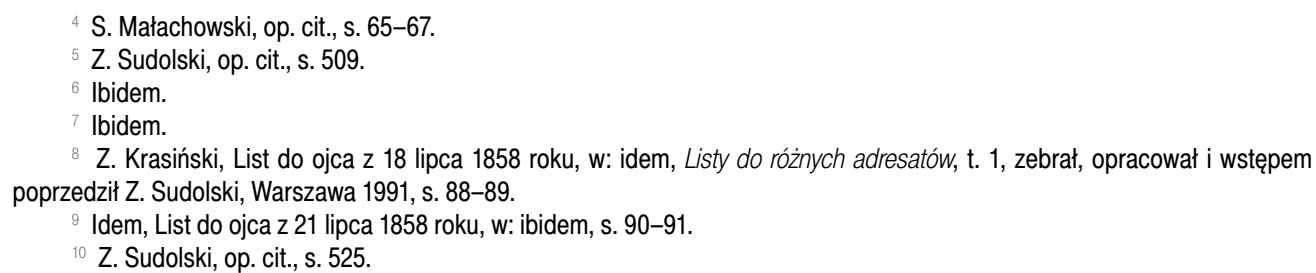

Druga audiencja

u cesarza odbyła się 20 lipca 1858 roku w Plombières 
siedemdziesiąte. To czasy ingerencji cenzury w publikowane książki. Oczywiste jest więc, że teksty, w których tak mocno było reprezentowane stanowisko antyrosyjskie, nie miały prawa ukazać się drukiem. Prawdopodobnie również ze względu na poglądy polityczne, które w tych dwu tekstach wyraził Krasiński, Jan Czubek umieścił je w tomie Pism filozoficznych i politycznych, następni edytorzy poszli zaś za tym przykładem edytorskim. Podczas opracowywania tekstów do nowej edycji krytycznej nasunęła mi się jednak pewna myśl - czy słusznie teksty te zostały umieszczone razem z innymi pracami o charakterze dyskursywnym?

Stownik terminów literackich podaje cztery definicje dyskursu: od tej najbardziej pojemnej, uznającej dyskurs za synonim każdej wypowiedzi, aż do tej tradycyjnej, w myśl której dyskurs „to wypowiedź zrygoryzowana logicznie, operująca argumentacją, traktowana jako przeciwstawienie wypowiedzi, w której dominują elementy perswazyjne bądź ekspresyjne, a także - wypowiedzi literackiej”11. Jak łatwo zauważyć, już w tej prostej definicji zawarto spostrzeżenie dotyczące różnic między tekstami dyskursywnymi a literackimi. Tekst literacki to - według Janusza Lalewicza - tekst potoczny, choć artystycznie zorganizowany. Jest pisany językiem potocznym i mówi o takiej rzeczywistości, jaką znamy z codziennego doświadczenia ${ }^{12}$. Teksty dyskursywne natomiast, do których zaliczają się m.in. wypowiedzi filozoficzne, są natomiast konstruowane „za pomocą pewnych metodycznych procesów myślowych w dziedzinie poszczególnych dyscyplin naukowych i koncepcji filozoficznych"13. Różnice między tekstami literackimi a dyskursywnymi będą

Literatura i filozofia mają jednak jeden wspólny cel: dążą do osiągnięcia tej samej prawdy zatem dotyczyły różnych kodów językowych, jakimi się one posługują, sposobów konstruowania tekstu, typów uniwersum tekstu oraz sposobów ujmowania rzeczywistości ${ }^{14}$. Literaturę cechuje emocjonalność, chętnie wykorzystuje ona wieloznaczność i raczej unika precyzji logicznej ${ }^{15}$. Teksty filozoficzne są zaś obwarowane rygorami formalnymi - muszą podporządkowywać się „logicznym regułom wywodu” ${ }^{\prime \prime}$. Lalewicz zauważa jednak, że takie ścisłe rozgraniczenie dwóch typów tekstów jest w praktyce niemal nieobecne: cechy tekstów dyskursywnych (ale tylko pewne cechy!) można odnaleźć w utworach literackich i odwrotnie - bardzo często teksty, choćby filozoficzne, zbliżają się swoją postacią do tekstów literackich ${ }^{17}$. Badacz podkreśla, że każdy tekst filozoficzny, nawet ten najbardziej zbliżony w swej postaci do tekstów literackich, odsyła czytelnika do jakiegoś uniwersum abstraktów, a nie do ,jednostkowego konkretu świadomości”, jak to dzieje się w przypadku utworu literackiego ${ }^{18}$. Literatura i filozofia mają jednak jeden wspólny cel: dążą do osiągnięcia tej samej prawdy, robią to jednakowoż przy użyciu odmiennych metod ${ }^{19}$.

Najpełniej potoczne ujmowanie rzeczywistości (czyli cechujące teksty literackie) według Lalewicza może być przedstawione za pomocą opowieści ${ }^{20}$. Autor dzięki uczestniczącym w opowieści aktorom i zdarzeniom oraz przedmiotom obejmuje zaledwie fragment rzeczywistości - to prawda, jednak jest to fragment na tyle złożony i obszerny,

Słownik terminów literackich, pod red. J. Sławińskiego et al., Wrocław 2000, s. 114-115.

J. Lalewicz, Opowiadanie i rozumienie, w: Wypowiedź literacka a mypowiedź filozoficzna, pod red. M. Głowińskiego i J. Sławińskiego, Wrocław 1982, s. 165

Ibidem, s. 166

${ }^{4}$ Ibidem.

${ }^{5}$ M. Michalski, Dyskurs - apokryf - parabola. Strategie filozofowania w prozie współczesnej, Gdańsk 2003, s. 18.

Ibidem, s. 19.

J. Lalewicz, op. cit., s. 167.

Ibidem, s. 169.

M. Michalski, op. cit., s. 24.

J. Lalewicz, op. cit., s. 170. 
by można było na jego podstawie zrekonstruować całościowy sposób ujmowania świata ${ }^{21}$. Krasiński porzuca język dyskursu na rzecz narracji - przedstawia określoną fabułę opartą na rzeczywistej audiencji, ujawnia aktorów, kreuje świat przedstawiony. Owszem, robi to w odniesieniu do realnych zdarzeń - wszak audiencje u Napoleona III są potwierdzonym faktem i możemy się spodziewać, że wydarzenia opisane przez polskiego poetę istotnie się zdarzyły. Nie jest to jednak opowieść dla samej opowieści - narracja staje się środkiem do celu, jakim jest przedstawienie sposobu postrzegania świata przez poetę.

We wstępnej części artykułu wyraźne rozgraniczenie literatury i dyskursu nie jest chyba możliwe. Krasiński nie uwolnił się w pełni od dyskursu. Ale przekazuje czytelnikowi swoją wizję rzeczywistości - spełnia przez to jedną z podstawowych funkcji literatury, a mianowicie funkcję poznawczą ${ }^{22}$. Nie robi tego za pomocą logicznego, rygorystycznego czy wręcz dogmatycznego, by użyć określenia Jacques’a Derridy, dyskursu. Wybiera w tym celu formę opowieści, a filozoficzna prawda o rzeczywistości i jego sposób patrzenia na sytuację polityczną w Europie objawia się w przyjętej przez niego strategii.

O sposobach filozofowania literaturą pisze m.in. Maciej Michalski w przywołanej tu już książce Dyskurs - apokryf - parabola. Strategie filozofowania w prozie wspótczesnej. Uważa on, że „filozoficzność tekstu literackiego można opisać w kategoriach strategii, którą stosuje autor, by wyrazić swój namysł i »dać do myślenia « odbiorcy”23. Strategia filozofowania jest przez niego rozumiana jako szczególne umiejscowienie podmiotu literackiego i odbiorcy, ukształtowanie wypowiedzi, wykreowanie świata przedstawionego oraz użycie odpowiednich środków artystycznych, które umożliwiają autorowi osiągnięcie jednego, nadrzędnego celu ${ }^{24}$ - wyrażenie własnych filozoficznych refleksji ${ }^{25}$, ale również zmuszenie odbiorcy do namysłu, swoiste włączenie go w pozornie jednostronny dialog. Michalski opisuje trzy strategie filozofowania za pomocą literatury. Chciałabym skupić się na jednej z nich, która w moim przekonaniu najlepiej odpowiada analizowanym tekstom Krasińskiego, tj. na strategii dyskursywnej.

Według Michalskiego konstytutywną cechą strategii dyskursywnej jest „brak fikcji, kreacji świata przedstawionego, wyeksponowana zostaje zaś kategoria podmiotu"26. Jak łatwo zauważyć, wszystkie te cechy możemy odnaleźć zarówno w tekście Pierwszego postuchania u Napoleona III, jak i w Drugim postuchaniu u Napoleona III (choć kreacja świata przedstawionego jest w nich obecna, to jednak nie jest tak rozbudowana, jak w przypadku innych utworów narracyjnych ${ }^{27}$. Kolejną istotną właściwością jest świadome odwoływanie się do dyskursu. W tekstach pisanych za pomocą strategii dyskursywnej można zauważyć, według Michalskiego, nieustające napięcie „między uporządkowanym dyskursem [w wypowiedziach bohaterów - E. Z.] a bezpośrednim wyrażaniem myśli [w wypowiedziach narratora - E. Z.]"28. Tak też dzieje się w przypadku dwu opisywanych przeze mnie tekstów - to właśnie Krasiński-narrator wyraża bezpośrednio swoje myśli, kreuje świat, który chce przedstawić. Wypowiedzi postaci mają natomiast wyraźny charakter dyskursywny. Każdy z dwóch bohaterów przedstawia swoje poglądy na sprawę polską oraz na

\footnotetext{
${ }^{21}$ Ibidem.

E. Mukoid, Jedność słowa. Rozważania na temat związków literatury i filozofii, „Ruch Literacki” 1987, z. 4-5, s. 363.

M. Michalski, op. cit., s. 36 .

Ibidem, s. 39.

Ibidem.

Ibidem, s. 41.

Wszak nie o przedstawienie i dokładny opis przestrzeni chodziło Krasińskiemu, lecz o zawarcie w owych tekstach swojej myśli politycznej.

M. Michalski, op. cit., s. 41.
} 
sytuację polityczną w Europie i, co ważne, robi to w sposób nieodbiegający od współczesnego rozumienia dyskursu. Teksty Krasińskiego mają charakter pamiętnikarski - są opatrzone dokładną datą, opisano w nich konkretne miejsca i wydarzenia. Wybór takiej, a nie innej formy Michalski uzasadnia chęcią autorów do „odrzucenia spetryfikowanych odmian dyskursu czy nawet wszelkich zabiegów organizujących tekst ponad niezbędny próg zrozumiałości”29. Krasiński-esteta wybiera zatem formę zapisków z dziennika (w domyśle literackiego), by nie skupiać się na rygorach formalnych dyskursu, i oddaje ważne dla siebie kwestie w sposób prosty, a przy tym niepozbawiony piękna. Brak jest również u Krasińskiego postulowanej przez Michalskiego redukcji literackości - wartość artystyczna tekstów romantyka jest wyraźna i niezwykle istotna. Wyraźnie dominuje w nich funkcja estetyczna języka. Użycie bogatego słownictwa oraz figur retorycznych w wypowiedziach bohaterów, operowanie środkami stylistycznymi w partiach narracyjnych - również przemawiają za literackością tekstów. Narrator jawi się jako swoisty polityczny esteta, który niezbyt obszernie, lecz z ogromnym wyczuciem stylu opisuje detale m.in. ubioru cesarza i miejsca audiencji. Co istotne, właśnie na postaci cesarza narrator skupia uwagę. W omawianych tekstach pojawiają się neologizmy („zmonarszeć na powrót”), pytania retoryczne, metafory („myśli ukrytej najzwięźlejsze wyrażenie”, „szabla turecka rozcięła ich dzieje”), antropomorfizacje („[Francja] własnymi wciąż rękoma rozdzierać się będzie”) oraz rozbudowane, oryginalne porównania. W tekstach Pierwszego i Drugiego postuchania u Napoleona III można też dostrzec świadome użycie elementów wyrażających emocje, szczególnie we fragmentach odnoszących się do postaci cesarza - tu najwyraźniej widać emocjonalny stosunek narratora do wielkiego wodza oraz do sytuacji spotkania z cesarzem.

Krasiński-esteta wybiera zatem formę zapisków z dziennika
Za pomocą strategii dyskursywnej Krasiński daje wyraz swojemu filozoficznemu sposobowi postrzegania rzeczywistości. Możemy rozpatrywać go na dwóch poziomach.

1. W konstrukcji fabuły, przestrzeni oraz bohaterów-aktorów, w sposobie prowadzenia narracji - zauważamy wówczas punkt widzenia Krasińskiego-narratora, jego stosunek do świata jako całości.

2. W wypowiedziach autora-bohatera podczas jego konfrontacji z Napoleonem III - tu z kolei można zauważyć szczególny stosunek poety do cesarza, wyraz nadziei, jakie wiązał z odbywanymi rozmowami, oraz poglądy Krasińskiego (znane również z korespondencji) co do sytuacji politycznej Europy.

W ramy fabuły Krasiński wprowadził więc to, co równie dobrze mógłby ująć za pomocą typowego języka dyskursu. Postanowił jednak posłużyć się narracją, elementy dyskursu pozostawiając w wypowiedziach dwóch głównych protagonistów sytuacji narracyjnej. Dzięki wykorzystaniu języka literackiego oraz formy literackiej przybliża czytelnika do sedna sprawy - daje pełniejszy wgląd w obraz ważnej patriotycznej kwestii. Przedstawia pewne „tu i teraz” (oczywiście z konieczności przedstawione jako minione, a więc raczej „tam i wtedy”), polityczny kontekst rozmowy, konkretne postaci oraz przytacza ich wypowiedzi. Z tych wszystkich elementów opowieści wyłania się wyraźny obraz świata.

Omawiane w tym artykule teksty Zygmunta Krasińskiego są ciekawe co najmniej $\mathrm{z}$ dwóch powodów. Pierwszym jest fakt biograficzny - relacjonują one ważne momenty w życiu romantyka. Drugi powód jest bardziej złożony, umożliwia bowiem przeniesienie Pierwszego i Drugiego postuchania u Napoleona III z obrębu pism filozoficznych i politycznych do tomu zawierającego prozę artystyczną. To propozycja dyskusyjna. Motywuje ją brak obecności języka czystego dyskursu zarówno w pierwszej, jak i drugiej wypowiedzi

Ibidem, s. 42. 
Krasińskiego oraz narracyjny charakter obu tekstów. Kolejnym argumentem może być walor artystyczny, zbliżający omawiane teksty do wypowiedzi historiograficznych w rozumieniu Haydena White'a, dla którego nauka o historii korzysta z tych samych form i stylów wypowiedzi, co literatura. Krasińskiemu nie chodziło jednak o szczegółowe przedstawienie historycznych wydarzeń, a więc audiencji u cesarza Napoleona III, lecz o wyrażenie w nich własnych poglądów, przekonań i emocji w formie zbliżonej do zapisków z dziennika literackiego.

\section{Zasady edycji}

W tekstach zmodernizowano grafię, ortografię oraz interpunkcję zgodnie z obowiązującymi dzisiaj zasadami. Uwspółcześniono pisownię wielkiej litery, zostawiając ją w zwrotach grzecznościowych oraz wyrazach nacechowanych ekspresywnie. Modernizacja objęła również końcówki gramatyczne wyrazów („-em”, „-emi”), zachowano zapis nazw państw w rodzaju żeńskim typu „Francya”, „Austrya”, „Rosya”, gdyż jest to pisownia jednolita w całym tekście. Podkreślenia autora zaznaczono pogrubieniem czcionki.

\section{Wykaz skrótów}

JCz - Z. Krasiński, Pisma. Wydanie Jubileuszowe, t. 7, oprac. J. Czubek, Kraków-Warszawa 1912.

LP - Z. Krasiński, Dzieta, t. 11-12, oprac. L. Piwiński, z przedmową M. Kridla, Warszawa 1931.

PH - Z. Krasiński, Pisma filozoficzne i polityczne, oprac. P. Hertz, Warszawa 1999.

\section{Uwagi edytorskie i ważniejsze odmiany tekstowe}

Pierwsze postuchanie u Napoleona III

napadajac ostateczne jej pogranicza | napadajac ostateczne jej pogranicza LP | napadajac ostatecznie jej pogranicza $\mathrm{PH}$

Polski, pod pewnymi względami samoistnej, rządzonej osobno| Polski, pod pewnymi wzgledami samoistnej, rządzonej osobno LP | Polski pod pewnymi wzgledami samoistnej, rzadzonejosobno $\mathrm{PH}$

wydaje możliwym i praktycznym | wydaje jedynie możliwem i praktycznem $\mathrm{JCz} \mid$ wydaje możliwem i praktycznem LP | wydaje możliwym i praktycznym $\mathrm{PH}$

wyobrażenia o honorze | wyobrażenie o honorze $\mathrm{JCz} \mid$ wyobrażenia o honorze $\mathrm{LP} \mid$ wyobrażenia o honorze $\mathrm{PH}$

byt wyrzekt frazes $\mid$ byt wyrzekt ten frazes $\mathrm{JCz} \mid$ byt wyrzekt frazes $\mathrm{LP} \mid$ byt wyrzekt frazes $\mathrm{PH}$
W podstawie tekstowej dostrzeżono występowanie dodatkowych słów, których nie ma w innych edycjach 
W podstawie tekstowej dostrzeżono występowanie dodatkowych słów, których nie ma w innych edycjach. W tekście głównym przyjęto zatem lekcję Leona Piwińskiego oraz Pawła Hertza, którzy uznali te słowa za dodane przez Jana Czubka.

W zdaniu „[...] dążyć ku sercu Moskwy, jedno wypadało mi, napadając ostateczne jej pogranicza, zmuszać jej wojska do długich i nużących pochodów na to, by dopiero wyniszczone i o połowę zmniejszone dochodziły do punktu przez nas napadanego" Paweł Hertz w swoim wydaniu zmienił przymiotnik „ostateczne” na przysłówek „ostatecznie”. Zdecydowano się na przyjęcie wersji Czubka (tym bardziej że tak samo postąpił Piwiński, który również pracował z rękopisami), ponieważ ze struktury zdania wyraźnie wynika, że przymiotnik ten, będący w tym znaczeniu synonimem słowa „skrajny”, odnosił się do wyrazu „pogranicza”. Zmiana części mowy powoduje zmianę sensu zdania.

Za Czubkiem zachowano również interpunkcję w zdaniu: „[...] przyłączenia jej do Królestwa i utworzenia z nich Polski, pod pewnymi względami samoistnej, rządzonej osobno przez członka rodziny cesarskiej moskiewskiej”. Usunięcie wtrącenia, którego dokonał Hertz, zmienia znaczenie zdania.

Edycja Czubka zawiera sformułowanie „wyobrażenie o honorze”, Piwiński i Hertz przyjmują jednak wersję „wyobrażenia o honorze”. Słownik języka polskiego podaje, że użycie słowa „wyobrażenie” w liczbie mnogiej odnosi się do pojęć abstrakcyjnych, w liczbie pojedynczej natomiast - do ludzkiej pamięci. Przyjęłam rozwiązanie, które wybrali Piwiński oraz Hertz.

Drugie postuchanie u Napoleona III

$$
\begin{aligned}
& \dot{z} e \text { taka jego myśl byta } \mid \dot{z} e \text { taka myśl jego byta } \mathrm{JCz} \mid \dot{z} \text { e taka jego myśl byta } \mathrm{LP} \mid \text { że taka jego } \\
& \text { myśl byta } \mathrm{PH}
\end{aligned}
$$

jest jedność rodu ludzkiego - jest Ludzkość |jest jedność rodu ludzkiego, jest ludzkość JCz | jest jedność rodu ludzkiego - jest Ludzkość LP | jest jedność rodu ludzkiego, jest ludzkość PH

sprawa narodowości rozumie Ludzkość | sprawa narodowości rozumie ludzkość $\mathrm{JCz} \mid$ sprawa narodowości rozumie Ludzkość LP | sprawa narodowości rozumie ludzkość $\mathrm{PH}$

przypomina mi ona tagodność $\mid$ przypomina mi owa tagodność LP | przypomina mi owa tagodność $\mathrm{PH}$

W wydaniu Czubka w zdaniu „Nie ma żadnej wątpliwości - rzekł mi na to - że taką myśl jego była" nastąpiła zmiana kolejności wyrazów w stosunku do tekstu w wydaniach Piwińskiego oraz Hertza. W związku z tym, że Piwiński również korzystał z rękopisów, przyjęto jego rozwiązanie.

Także za Piwińskim przyjęto pisownię słowa „Ludzkość” wielką literą. W ten sposób zmienia się bowiem nacechowanie semantyczne tego wyrazu - ludzkość jest tu rozumiana jako zbiorowość i jednocześnie stanowi alegorię świętej sprawy Boga sankcjonującego człowieczeństwo. Uznajemy lekcję Piwińskiego za właściwą w kontekście wymowy utworu.

Pozostawiono też użyty w wydaniu Czubka zaimek „ona” zamiast, jak w wydaniach Piwińskiego oraz Hertza, „owa”. Należy zwrócić uwagę, że zaimek ten został użyty w funkcji, którą współcześnie pełni zaimek wskazujący „ten” (oczywiście w rodzaju żeńskim). Znaczenie zdania pozostaje niezmienne, jednak pozostawienie zaimka „ona” pozwala na oddanie charakteru współczesnej Krasińskiemu polszczyzny. 


\section{4 kwietnia 1857 o 3-ej z południa. O naznaczonej godzinie... [Pierwsze posłuchanie u Napoleona III]}

4 kwietnia 1857 o 3-ejzpotudnia

O naznaczonej godzinie, o drugiej z południa przyjechałem do ciotki. Oświadczyła mi, że niespodzianie poseł moskiewski dał znać, że przybędzie, u synowca posłuchania się domaga, i że do niej później ma przybyć. Zatem do sypialni mnie swej zaprosiła i tam siedziała ze mną, co chwila w niespokojności wychodząc do salonów przyległych, a rada, żem tak przyjechał, iż z posłem się nie spotkałem. Synowiec raz przyszedł do trzeciego salonu i z nią mówił już po odprawie posła, potem żona synowca i także w trzecim salonie z nią mówiła, dopytując się, gdziem schowan. Ona bowiem koniecznie była nalegała na męża, by widział się ze mną. Poseł tymczasem po posłuchaniu na górze był zszedł na dół do Ciotki; lecz że już czasu nie miał, tylko imię swe zapisał na przedpokoju i na konferencje się udał do Ministerium Spraw Zagranicznych. Jednak wciąż w sypialnim siedział. O trzeciej doniesiono ciotce ze mną siedzącej, że synowiec jedzie. Wyszła, przyjęła go, wróciła po mnie, wyprowadziła mnie i, mówiąc: »Il est sur des béquilles «, przedstawiła mnie jemu. Potem weszła nazad do swej sypialni, zostawując mnie z nim sam na sam.

Ujrzałem człowieka bladej twarzy, najuprzejmiejszych ruchów i wyrazu twarzy, niezmiernie w tej chwili uprzejmego. Czarny ubiór od stóp do głów; na fraku gwiazda brylantowa, wpół zakryta. Postać szlachetna, raczej arystokratyczna, raczej wielkiego bardzo pana niż monarchy; lecz znać było, że sam chciał tak wyglądać w tej chwili i że co chwila mógłby zmonarszeć na powrót.

» Charmé de faire votre connaissance « i kazał siedzieć na kanapie, sam usiadł na krześle szerokim.

Rzekłem mu, siadając: »Dzięki za tę chwilę szczęścia w życiu, bo szczęściem wielkim mnie, wychowanemu w miłości i czci Cesarza, móc oglądać Cesarza odżyłym w Tobie, Najjaśniejszy Panie«.

Uśmiechnął się słodko i natychmiast bez żadnych innych wstępów, zaczął mówić, jak następuje:

On. Gdyby wojsko nasze było zaraz (a to możliwym i nawet dość łacnym było) wzięło Sebastopol, wtedy można było iść na Ukrainę przez Mikołajew brzegami Dniepru. Pewny jestem, że wtedy by się Austrya była natychmiast oświadczyła za nami i Polską. W tym dowód tego leży, że za przyjściem fałszywej wieści o zdobyciu Sebastopola, zaraz kazała mi telegrafem winszować; za przyjściem zaś w rok później prawdziwej, żadnych od niej powinszowań nie odebrałem; już była się odmieniła, już nie chciała orężnie działać w naszym interesie i Polski. Moim zdaniem, nie chcąc powtórzyć błędu stryjowskiego, nie powinienem był (szczególniej, Austryi nie mając za sobą ani Prus) dążyć ku sercu Moskwy, jedno wypadało mi, napadając ostateczne jej pogranicza, zmuszać jej wojska do długich i nużących pochodów na to, by dopiero wyniszczone i o połowę zmniejszone dochodziły do punktu przez nas napadanego. Dobrzem to był wymiarkował i tak się stało. Zatem rozpocząłem od Krymu - inaczej niepodobieństwem było, nie mając ani Austryi, ani Prus za sobą, lub ich obu nie rozgniótłszy wprzódy gromami zwycięstw tak jak Napoleon. $\mathrm{Na}$ Litwę przez Połągę niezmiernie trudno było. Dużo o tym myślałem i przemyśliwałem, alem zawsze widział, że nie sposób przybijać z wojskiem do portu, zamarzającego na sześć miesięcy i to przy braku bliskiej potężnej twierdzy, w której by się można zaraz usadowić
Ujrzałem człowieka bladej twarzy, najuprzejmiejszych ruchów i wyrazu twarzy, niezmiernie w tej chwili uprzejmego 
i organizować. Tylko przez Rygę można było taką wyprawę odbyć, ale tam trafialiśmy na samym wstępie na całą rdzenną moc Moskwy.

Ja. Jednak, jeśli wolno to spostrzeżenie uczynić, nadmienię, że wojsko francuskie, wylądowując do Litwy, trafiało na drugą Francyą i że w miejscu twierdzy mogło obozy okopne stawiać i w sześć miesięcy mieć całą przestrzeń Polski zorganizowaną orężnie, gdyż wiadomo, że włościanin nasz w sześć tygodni czasu doskonałym staje się żołnierzem.

On. Co do włościanina polskiego wiem, że tak jest; lecz to wszystko, powtarzam, zdawało mi się w moich rachubach niepodobieństwem, skorom musiał działać bez Austryi. Teraz mówmy o obecnym położeniu. W polityce mówi się tylko o tym, co jest urzeczywistnialnym w danej chwili; w obecnej zaś dwa tylko przypuszczenia mamy przed sobą: pierwsze wojny olbrzymiej, przewracającej wszystkie stosunki i układy europejskie (grands bouleversements), a w takiej wojnie, kto odgadnąć potrafi, jak się ułożą przymierza pomiędzy państwami europejskimi? Zatem trudno co bądź o tej przypuszczalnej formie przyszłości powiedzieć. Drugie, na co zdaje się prawdopodobniej się zanosić, że trwać będzie stan pokoju i dyplomatycznych układów, rozstrzygających o świecie. Trzymajmy się więc owego drugiego przypuszczenia (hypothèse). W nim zdaje mi się, że jedynym sposobem pomożenia wam byłoby przystać na pewne ustąpienia Moskwie pewnych części państwa Otomańskiego pod warunkiem, przeze mnie jej nałożonym, zabrania Galicyi, przyłączenia jej do Królestwa i utworzenia z nich Polski, pod pewnymi względami samoistnej, rządzonej osobno przez członka rodziny cesarskiej moskiewskiej.

Ja. Niezawodnie, jeśli cesarz Mikołaj nie skasował tytułu Królestwa Polskiego, zniszczywszy, co tylko mógł, z Polski i przerobiwszy, o ile mógł, Królestwo na powiat cesarstwa moskiewskiego, to, że myśl w gabinecie petersburskim panuje za pomocą i na mocy tego tytułu kiedyś opanować Księstwo Poznańskie i Galicyą.

On. W układach, o których nadmieniam, trzeba by o Księstwie Poznańskim zapomnieć, bo Moskwa, w ścisłym spoju z Prusami, nie chciałaby na Prus rozbiór przystać. Na samej Galicyi należałoby przestać. To mi się wydaje możliwym i praktycznym w tej chwili. Można by przy tym cesarza Aleksandra pewnymi zachętami do wielkości i wspaniałomyślności w serce uderzyć. Lecz oczywiście w polityce coś się tylko robi za coś. Żebym wciąż ich tylko prosił o ulgę dla Polski i nic im nie dał, wciąż by mi tylko frazesami marnymi odpowiadali, jak Orłow na wiosnę, obiecywali, a nie dotrzymywali; a gdybym powtarzał tylko próżne nalegania, choćbym i teraz W. księciu Konstantemu jak najpiękniejsze rzeczy w tym gatunku mówił, mogliby wreszcie mi odpowiedzieć: »To nasze sprawy, własne nasze, nie mieszaj się do nich «. Wojną wprost dobijać się o Polskę nie mogę dziś; cóż mi więc pozostało, jeśli nie przyobiecanie im pewnych korzyści, a wtedy położenie za warunek do ich otrzymania tego, com wyżej powiedział? Wszystko reszta w obecnym położeniu na nic się nie zda!

I przydał tu: » Ce que je vous dis, vous en sentez, est fort confidentiel «.

$J a$. Toby dla nas było ze wszystkich dróg przypuszczalnych, mających nam służyć do zmartwychwstania, najboleśniejszą - nie wiodłoby nas bezpośrednio, jedno pośrednio do celu. Dla nas najszczęśliwszą drogą wskrzeszenie bezpośrednie przez Francyą.

On. Prawda, ale na to wojny potrzeba.

Ja. Moskwa szczerze nigdy nic dla Polski nie może uczynić, bo jej istotnym interesem jest śmierć Polski. Wszystko dzieli te dwa narody, wszystko w nich walczy przeciwko sobie: religia, język, przeszłość cała, wszystkie wyobrażenia, nawet wyobrażenia o honorze.

On. Prawda - wiem - ale Niemcy przynajmniej mogłyby mieć interes w postawieniu Polski. 
Ja. Tak, gdyby się nie były stały wspólnikami złego, gdyby rąk nie były zanurzyły w głąb tej samej zbrodni. Wspólnictwo zbrodni takiej jest przyrody, że w ostatecznym wyniku nie dozwala już pilnowania się własnego interesu nawet.

On. Prawda.

Ja. Lecz Francya ma żywotny, wieczny interes w odżyciu i życiu Polski. Cokolwiek wypadnie, pamiętaj, N. Panie, o narodzie, który jeden ze sławiańskich jest w pełni katolickim, zachodnim, jest koniecznym Francyi sprzymierzeńcem i do tego najwierniejszym był dynastii twojej. Pamiętaj o nim, Najjaśniejszy Panie, dla siebie samego i ze względu na przyszłe losy syna twego. Pamiętaj, Najjaśniejszy Panie, nie dać go zatracić. Co możesz, w każdej zdarzenności czyń.

On. Francya tych samych ma trzech wrogów, co Polska. W tym jej smutne położenie, że sama jedna przeciwko nim trzem bić się nie może.

Ja. Niechże tak uczyni, jak Horacjusz z Kurjacjuszami: niech ich rozdzieli i każdego z osobna pokona.

Rozśmiał się uprzejmie, jakby trafion tym miło w serce, jakby te słowa były jego myśli ukrytej najzwięźlejszem wyrażeniem, i istotnie ten uśmiech znaczył tyle co: Tak! - i zapytał o Galicyi stan.

Wspomniałem o rzeziach 1846, o tej zdradzieckiej zbrodni rządu rakuskiego, o nadaniu w rok później gruntów włościanom, jakby na wprowadzenie w świat zasady, że zbrodniom należy się nagroda i korzyść, o chorobach, co później w skutku wyrzutów sumienia nękały włościan, którzy należeli do rzezi, o mistycznym kierunku słowiańskiego sumienia, wreszcie, że ci sami włościanie galicyjscy odstrychnięci dziś od rządu rakuskiego. W końcum dodał: Śród Moskwy, Prus i Austryi, choć nie ukrzyżowaliśmy Boga, choć samiśmi ukrzyżowani raczej, prześladowanym my dziś plemieniem, jak żydowskie. Prześladowaniu mikołajewskiemu, doznanemu przez Polskę, nie ma równego w dziejach, chyba że się udamy do czasów asyryjskich lub do obchodzenia się cezarów rzymskich z hebrajskim narodem.

Przystał na to, lecz znów powtarzał, że chyba wojną można by naszej niedoli zaradzić inaczej, niż tym, czym on zamyśla pomóc nam w obecnym stanie rzeczy. A już z początku był wyrzekł frazes: Wojna teraz nie jest prawdopodobna z Moskwą, my się raczej teraz umizgamy do siebie (nous sommes plutôt en coquetterie avec la Russie).

Wciąż przy tym jednak obiecywał, że w każdym razie, w jakim bądź przypadku i obrocie rzeczy, będzie czuwał nad narodem polskim i starał się o jego dobro.

Po trzech kwadransach lub godzinie rozmowy sam na sam, podczas której sam prawie ciągle przemawiał, i to nadzwyczaj gładko, płynnie, uprzejmie, łagodnie, niewymuszenie, tak, jak człowiek, co mówi jak najszczerzej i zarazem jak najprzychylniej, a liczy na to, że słuchacz nie powtórzy słów słyszanych, wstał, podał mi rękę, którąm ścisnął z lekka i z głębokim wyrazem uszanowania, i rzekł: »Miło mi, żem poznał Pana Hrabiego«. Ja wtedy: »Przyjm, Najjaśniejszy Panie, najgłębszy wyraz mej wdzięczności, ale dozwól, dozwól, bym raz jeszcze cię zaklął o pamiętanie o narodzie polskim«.

Skłonił się uprzejmie i rzekł: »Nie zapomnę《, trochę rękę podnosząc do góry.

Potem wyszedł z salonu; ale wnet wrócił, pobiegł ku drzwiom sypialni ciotki - rozemkną je - zawołał na nią - wprowadził ją nazad do salonu - coś z nią mówił, a potem rzekł, gdy go odprowadzała do przeciwnych drzwi, którymi miał już wychodzić: »Przyjm moje dzięki, droga ciotko, za zapoznanie mnie z Hrabią« i znikł.

\section{Lecz Francya ma żywotny, wieczny interes w odżyciu i życiu Polski}




\section{0 lipca 1858 r. w Plombières. O drugiej według rozkazu... [Drugie posłuchanie u Napoleona III]}

\section{0 lipca 1858 r.w Plombières}

O drugiej według rozkazu mi przez księżnę Hamilton przesłanego stawiłem się na przedpokoju cesarskim. Minister sardyński Cavour, przybyły w nocy, od trzech godzin już z nim rozmawiał. Generał od służby, Béville, poprosił mnie do pokoju swego - tam czekałem z pół godziny. Skoro Cavour wyszedł, zaraz cesarz kazał mię zawołać. Wszedłem. - Stał przy kominie - podał mi rękę. Doskonale wyglądał, otylszy niż przeszłego roku, i nie taki blady.

- Dzięki ci składam, Najjaśniejszy Panie, żeś mi nazad dozwolił szczęścia oglądania ciebie.

Zaprosił do siedzenia, siadając sam.

- Czyś za kuracją przybył?

- Tak.

- Aleś lepiej niż przeszłego roku, bo już bez kul.

- Choć bez kul, Najjaśniejszy Panie, owszem gorzej, gdyż roku zeszłego rana na kolanie zewnętrzna przypominała zewnętrzną wojnę; a teraz przerzuciło mi się zło w bole wewnętrzne, na kształt rewolucji społecznej - a to gorsze od wojny.

Zapewne - odrzekł z uśmiechem.

Spytał się o Elizę. Odparłem, że nad morzem w Trouville. Dalej:

- Wszak możesz wracać do kraju, nie jesteś emigrantem?

- Nie byłem i nie jestem. Niegdyś cesarz Mikołaj, nim Wasza Cesarska Mość uwolniłeś nas od niego, ścigał mnie i utrudniał paszporta, lecz teraz dają.

O stan Rosyi zaczął się wypytywać.

Szlachta rosyjska postanowiła - rzekłem - że nie odstąpi prawa swego od jednej piędzi ziemi, choć da wolność chłopom; stąd powstanie między nią a rządem starcie się. Przed kilką dniami w Vichy generał Roztopcow rzekł, mówiąc o właścicielach rosyjskich: »Tego roku im jeszcze nic nie będzie, ale na przyszły niech się strzegą

- C'est une grosse affaire.

- W istocie, Najjaśniejszy Panie, i tak to sprawa coraz groźniejsza, że nie dziwiłbym się wcale, gdyby rząd rosyjski dla zyskania czasu, dla odwleczenia rzezi społecznej użył jedynej zasady, to jest wojny z Niemcem, bo to jedno by jeszcze mogło na czas uwagę mużyków ściągnąć ku czemu innemu.

Zapytał się, co to mużyk. Jam chciał takim skrętem wprowadzić rzecz moją i ciągnąłem dalej:

- Bo w istocie i we Francyi też wojna tylko może rewolucji społecznej przeszkodzić. - Tak - ale une guerre juste.

- Oczywiście, ale czyż nie dość niesprawiedliwości po świecie na to, by móc w każdej chwili sprawiedliwą wojnę rozpocząć?

Rozśmiał się.

Dalej ciągnąłem: Najgłówniejszą w świecie niesprawiedliwością jest uciemiężenie narodowości - wojnę wypowiedzieć o tę świętą zasadę. Stryj twój, Najjaśniejszy Panie, wyrzekł: »Pierwsze lepsze książątko, co dobędzie miecza w sprawie narodowości europejskich, będzie panem świata«. Wyraził się w istocie peuples, a nie nations - lecz pewno nie myślał o motłochu, jedno o narodach całych.

- Nie ma żadnej wątpliwości - rzekł mi na to - że taką myśl jego była. 
- Zbaw, Najjaśniejszy Panie, Francyą i świat, wydobądź narodowości z więzów je pętających. Przeszłego roku nie śmiałem ci pewnych rzeczy mówić, lecz teraz, od kiedym w życiu przebył strasznego niepokoju pół godziny na bulwarach, biegnąc ku Operze, dnia zamachu i wypytując się wszystkich: A cóż z Cesarzem się dzieje? a odpowiadali jedni: »Nie wiemy« - drudzy: »Podobno ranny«; odkąd niebezpieczeństwo cię otacza, Najjaśniejszy Panie, muszę szczerze, co myślę, przed tobą wypowiedzieć.

- Byłeś na bulwarach o tej porze?

I zesmutniały mu rysy nagle.

- Byłem, Najjaśniejszy Panie, więc powtarzam: zbaw Francyą i świat. Zawszem myślał, że czym Joanna d'Arc przysłużyła się Francyi, tym Francya powinna światu: wydobyciem spod jarzma narodowych pierwiastków. To Francyi powołaniem istotnym i nim go dopełni, nie spocznie, ale sama własnymi wciąż rękoma rozdzierać się będzie. Wasza Cesarska Mość wyrzekłeś: Cesarstwo pokojem - i prawda, lecz niechże to będzie pokój godny tego nazwiska, stały, długi, wieczny, jeśli co na ziemi tego przydomku brzemię znieść zdoła; niech to będzie, jakby Anglik powiedział, an imperial peace, a do takiej imperial peace jakże trafić, jeśli nie wojną, ostatnią może - ależ wojną zawsze, bo czyż dzisiejszy pokój ma jakie bądź w sobie rękojmie bytu? Czyż co chwila się nie rwie i rwać się nie będzie?

$\mathrm{Na}$ to wszystko przystawał, potakując, ale powtarzając: »Tak jest, ale to niezmiernie trudne. Rządy europejskie tak mało mają samoistności i d'initiative«.

- Wszystko trudnym, prawda - ale tylko trudnymi czynami można świat zbawić od społecznego zamętu, najstraszniejszego, jaki był w dziejach, a grożącego zniszczeniem tej epoce - per angusta ad augusta, Najjaśniejszy Panie!

- Trzeba czekać, aż się okoliczności same nasuną, a wtedy z nich korzystać, lecz nikt okolicznościami nie rządzi.

- Czasem jednak są ludzie, którym powołanie zsyła Bóg, i ci kierują okolicznościami. Zważ też, Najjaśniejszy Panie, że sprawa narodowości wręcz sprzeczna i przeciwna socjalizmowi, że ona jedna potrafi socjalizm zabić. Ideą epoki i przyszłości jest jedność rodu ludzkiego, jest ludzkość. Socjaliści twierdzą, że ona powinna się składać z jednostek bezróżnicowych, nieznających, co granice, podania, dzieje rozmaite, podciągniętych pod strychulec absolutnej równości; radziby zarzucić Bogu, że ciało ludzkie nie powinno się składać z rozmaitych członków, ale być tylko powtórzeniem kilkokrotnym tej samej nogi lub ręki.

Bardzo to porównanie trafiło mu do umysłu i potakiwał wciąż, śmiejąc się.

- Przeciwnie sprawa narodowości rozumie ludzkość jako harmonię rozmaitych członków, osobistości i kształtów; zatem wywołana, musi z socjalizmem walczyć. Lecz dziś cóż się dzieje? Narody spętane, związane, nie mogą zadać fałszu teorii socjalistów, bo krępuje je śmierć. Ci korzystają z tego i do swojej ludzkości mnóstwo oszukane powołują.

- Wszystko prawda, lecz socjalizm jest fałszem. Żaden fałsz nie potrafi długo się utrzymać.

- Owszem, Najjaśniejszy Panie; racz spojrzeć na historią: ile to fałszywych teorii rozkwitło i panowało i trwało długo, grasując po świecie. Natura ludzka skłonna do omamiania się.

Wtedy odezwal się:

- Teraz nawet nowo narodzone czy odkryte występują narodowości, o których nikt nie słyszał.

Na to ja:

- Ale ten, co w tej chwili ma zaszczyt przemawiania do Waszej Cesarskiej Mości, zdaje się, należy do starożytnej dość i dość znanej. Zresztą i tamte słowiańskie, o których 
mówisz, Najjaśniejszy Panie, jak Montenegryni, Serbowie, także od wieków istną, tylko że szabla turecka rozcięła ich dzieje. Przed podbojem muzułmańskim znano ich w świecie, a dziśs starają się wrócić na powierzchnią dziejów. Jednak to pewna, że na tle plemienia słowiańskiego tylko dwie prawdziwie potężne wyrobiły się narodowości: rosyjska i polska.

Tu mnie zagadt:

- Ilekroć o Polskę się dopytuję, mówią mi, że szlachta jak najwierniej przechowała ojczyźniane podanie, lecz że lud, którym opiekowały się rządy zaborcze, do nich się całkiem, jak w Galicyi, w skutku tej opieki przywiązał i że za szlachtą by nie poszedł walczyć o ojczyznę.

- W Galicyi nawet, Najjaśniejszy Panie, wielka i dziwna zmiana we włościanach pod tym względem. Odkąd dano im grunta na własność, miłość ich do rządu całkiem ostudzona, bo jako właściciele weszli w cochwilne stosunki podatkowe i inne z biurokracją austryacką, niezmiernie ich gniotącą i zdzierającą. Stąd nawrot ich do myśli bardziej polskich. W Księstwie zaś Poznańskim lud całkiem ojczystych podań się trzyma, w Królestwie i na Litwie tak samo. W danym razie, gdyby wojsko jakie ukazało się za Polską na polskiej ziemi, wszyscy by włościanie za szlachtą poszli. Na Ukrainie może inny duch u ludu, bo inna wiara; tam schizma. Zresztą tam pierwiastek polski był podbijającym, lud więc do Polski nie przywiązan - lecz i do Moskwy wcale nie, a od okoliczności zbiegu by zależało, na czyją by stronę się rzucił.

Tu wyrzekł słowa następujące:

\section{Trzydziestego roku mieliśmy trzydzieści tysięcy wojska wyborowego}

- Niepowetowana szkoda, że podczas wojny ostatniej nic nie zrobiono.

Ja, myśląc, że to się odnosi do państw zachodnich, które nic dla Polski nie uczyniły, odrzekłem:

- Zapewne, że nieodżałowana szkoda.

Tymczasem spostrzegłem ze słów jego dalszych, że chciał powiedzieć, iż w Polsce powinno było zdarzyć się powstanie.

- Obiecywano nam takoż - dodał - że oficerowie Polacy, których tylu w wojsku rosyjskim, przejdą do nas natychmiast; tymczasem prawie żaden nie przeszedł.

- Bo, Najjaśniejszy Panie - odrzekłem - do ojczyzny tylko bez hańby dezerterować można, a gdzież był wywieszon sztandar ojczyzny polskiej w francuskim obozie? Nawet zdarzyło się, że raz żołnierzy polskich, przeszłych z obozu rosyjskiego, wydał generał francuski nazad Rosyanom. Raz tylko zdarzyło się, ale zdarzyło się. Do czegoż więc, gdy Polski nikt nie ogłosit, mieli oficerowie Polacy dezerterować?

- Ale przecież był oddział Polaków z naszej strony.

- Były indywidua nieliczne, lecz oddziału nie było żadnego pod Sebastopolem. Dopiero w końcu samym wojny stanęła legia Władysława Zamojskiego, wnet ogłoszeniem pokoju rozwiązana. Powstania zaś w Polszcze być żadnego nie mogło, bo się z scyzorykami tylko w ręku nie powstaje, a od lat trzydziestu Europa dozwala nas rozbrajać i prześladować, i zatracać. Trzydziestego roku mieliśmy trzydzieści tysięcy wojska wyborowego; w kilka miesięcy później koło tego potężnego jądra czterdzieści tysięcy świeżego już się było utworzyło. Teraz zaś zupełnieśmy rozbrojeni i dopiero za wstąpieniem w granice Polski wojska obcego mogłaby Polska się zerwać i pod jego zasłoną w sześć miesięcy do boju się zorganizować; inaczej nie sposób jej palcem ruszyć.

Wtedy zaczął się pytać o cesarza Aleksandra:

- Wszak dobre ma chęci?

- W istocie dobre, ale ich urzeczywiszczenia nie widać, bo mu się sprzeciwiają państwa jego urzędnicy. Pan Muchanow przy bezczynności księcia Gorczakowa panuje 
w Królestwie, rządzi wszechwładnie, niweczy wszystkie cesarskie owe lepsze chęci. Sprzeciwił się przywróceniu Uniwersytetu, nie dał powstać szkole prawnej, pozwolił tylko na jednoroczny kurs prawa, a postanowił ostatnią diecezją greko-unitów, pod berłem rosyjskim będącą w Królestwie, oderwać od schizmy i dokaże swego.

Tu zapytał się, co to za diecezja, co to za grecy-unici. Znać wcale a wcale z tą kwestią nie obznajomion. Pokrótce opowiedziałem mu, jak cztery miliony unickiego ludu najokropniejszymi gwałty cesarz Mikołaj przywiódł na Litwie do schizmy, jak podczas tego prześladowania bito kijami wsie całe, wybijano zęby zakonnicom, katowano księży wiernych unii (aż się wzdrygnął) i wytłumaczyłem mu, że teraz chodzi Muchanowowi o trzykroć sto tysięcy ludzi, o ostatek ludu unickiego pod panowaniem moskiewskim i że jego ostateczne oderwanie wielkim stanie się ciosem i dla kościoła, i dla ducha polskiego.

To zrozumiał zaraz.

- Co zaś - dodałem - tyczy się łagodniejszego obchodzenia się z nami, któremu pod pewnym względem nie można zaprzeczyć, choć dawny systemat odnaradawiania nie odmienion, przypomina mi ona łagodność, że nieraz, gdy skazany na kilka tysięcy kijów żołnierz moskiewski już kona po wzięciu dopiero ich połowy, odprowadzają go do szpitala, tam łagodnie z nim także się obchodzą, opatrują mu rany, aż wyleczą, a wtedy znów na miejsce męki wiodą, doliczają ilość nieodebraną kijów i tą już razą trupem kładą. Lękam się, czyśmy i my dziś nieodprowadzeni do szpitala?

Smętnym głowy kiwnięciem zgodził się z tą uwagą, jak gdyby sam nie ufał w żadne moskiewskie obietnice, względem nas czynione, i zapytał się mnie, czy znam cesarza austryackiego.

- Osobiście nie, Najjaśniejszy Panie, ale dużo o nim słyszałem. Generał Haynau opowiadał, że gdy go wyprawiał na Węgry, rzekł mu: Machen Sie alles, was Sie wollen, bloss keine Gnade, i tym się zastawiał Haynau przed ścigającym go zarzutem okrucieństwa. Twierdzą dalej, że od wstrząśnienia mózgu nastąpionego w skutku uderzenia z tyłu czaszki nożem przez zabójcę zmiękło jego srogie pierwotne usposobienie, że się łagodniejszym stał. Kocha się szalenie w polowaniu i podobno niczym innym się nie zajmuje. Bach wszystko robi.

- I Buol - przerwał - Buol, który bardzo przykrym jest człowiekiem.

Wróciła znów rozmowa do Polski.

- Otóż - rzekł - Austrya mogłaby Polskę postawić, interes nawet w tym ogromny by swój miała.

- Tak, Najjaśniejszy Panie, nawet o tym wspominała już sama z siebie podczas wojny, ale zapewnie z czystej obłudy, bo postawienie Polski obaliłoby podstawę logiczną państwa, co ze samych Polsk zagarniętych i uciskanych się składa - toż trzeba by zaraz i Czechy,

i Węgry, i Lombardyą odbudowywać na tej samej zasadzie.

- Nie pojmuję - rzekł - ich zaślepienia w przeprowadzaniu jednolitości administracyjnej i prawnej państwa, ze samych różnych narodowości złożonego, kiedy by przeciwnie powinni na utrzymanie się jak najbardziej sprzyjać rozmaitemu obyczajowi tychże narodów.

- To też, Najjaśniejszy Panie, te narody wszystkie kipią.

- Czechy, zdaje mi się, przywiązane do domu austryackiego?

- To jest, niemieckie rody, osiadłe w Czechach po wytraceniu czeskich, ale nie czeska ludność; ta nie cierpi Niemców.

Rozmowa znów wróciła do Polski. Wspomniałem o pewnych frazesach austryackich, niby to żałujących rozbioru, o Marii Teresie i przytoczyłem słowa, które własną ręką przydała do podpisu swego na akcie podziału: »Ich tue es, weil so kluge und erfahrene 
Männern(s) es wollen - aber wenn schon lang tot ich bin, man wird erfahren, was aus dieser Verletzung von allem, was rechtes und heiliges ist, hervorgehen wird «.

Nie był słyszał o tym; ogromnie te słowa go zastanowiły. Doskonale umie po niemiecku i zrozumiał je zaraz. Wspominałem też o cesarzu Franciszku, który raz przy obiedzie z żoną, gdy twierdziła, że nieraz zbrodnie pozostają ukryte i na ziemi kary nie odbierają, zerwał się, rzucił serwetę na stół i przechadzając się w pomieszaniu, zawołał: »Nieprawda patrz, jak nas Bóg karze za zabór Galicyi: ja spać czasem od wyrzutów nie mogę po nocach «. I tum dodal:

- Rosyanie też dają się nieraz słyszeć z tym, że rozbiór Polski był błędem, był występnym czynem. Wszyscy zaborcy żałują, doznają zgryzot, ale...

Przerwał mi, dokończając myśli mojej:

- Wszyscy żałują, ale żaden nic nie zrobi.

Coś o Anglii się zgadało i rzekł, gdym twierdził, że ona zaczęła upadać:

- Od wyjścia Palmerstona z Ministerium to kraj bez rządu.

Nareszcie wstal i rzekł mi:

- Mam nadzieję, że przed moim wyjazdem stąd jeszcze się zobaczymy.

Ścisnął mi rękę, a gdym odchodził ku drzwiom, któremim był wszedł, przyprowadzon przez generała Béville, odwołał mnie, mówiąc, że trafię na labirynt korytarzy, i ku innym poszedłszy, sam mi je otworzył i nimi wypuścił: »Tędy prostsza droga«.

Przeszłej wiosny 1857 r., gdym go oglądał, daleko był żywszym, lekszym, pogodniej-

Sam rzadko się odzywał i krótkim zawsze słowem lub zapytaniem tylko szego, jakby zwycięskiego ducha, daleko bledszą miał cerę, mniej żółto i chudziej wyglądał. Przez cały czas sam mówił z rzadką płynnością o dziejach wojny i losach Polski. Ledwom mógł kilka słów śród jego własnych wcisnąć. Tą razą zaś przez pół godziny czy trzy kwadranse mnie dał ciągle prawie mówić. Sam rzadko się odzywał i krótkim zawsze słowem lub zapytaniem tylko. Wydawał się zesmutniały, jakby zwątpiały, wzdychał za skończoną wojną, nie rozświecał żadnych widnokręgów na przyszłość, coś mu zdawało się ciężyć. Słuchał uważnie wszystkiego z niezmierną uprzejmością i z zajęciem, ale najczęściej powtarzal, że wszystko jest trudnym. Lecz wiem, że miewa takie pory w życiu i że z nich się wydobywa, by nieprzewidzianymi czynami działać. 